\title{
Alkaline phosphatase activity in symbiotic dinoflagellates (zooxanthellae) as a biological indicator of environmental phosphate exposure
}

\author{
Eric R. Annis*, Clayton B. Cook \\ Harbor Branch Oceanographic Institution, 5600 US 1 North, Fort Pierce, Florida 34946, USA
}

\begin{abstract}
Alkaline phosphatase activity (APA) is an indicator of phosphorus status in marine plants. We examined APA in the symbiotic dinoflagellate Symbiodinium bermudense, which occurs with the sea anemone Aiptasia pallida. We have developed an assay for APA that serves as a biological indicator of inorganic phosphate $\left(\mathrm{P}_{\mathrm{i}}\right)$ exposure in coral reef environments and phosphorus deficiency in zooxanthellae. Zooxanthellae maintained in culture responded to a lack of $P_{i}$ with elevated levels of APA. Laboratory experiments with A. pallida demonstrated that this effect occurs in symbiosis, although at a longer timescale. The addition of $\mathrm{P}_{\mathrm{i}}$ to ambient sea water resulted in higher zooxanthellae density in unfed anemones compared to unfed controls maintained without additional $\mathrm{P}_{\mathrm{i}}$, indicating that $S$. bermudense can utilize exogenous sources of $\mathrm{P}_{\mathrm{i}}$. APA was measured in zooxanthellae from the coral Montastraea faveolata collected from 2 reef sites with different phosphorus exposure. Zooxanthellae from corals at the low $\mathrm{P}_{\mathrm{i}}$ site had significantly higher APA levels than those from the high $\mathrm{P}_{\mathrm{i}}$ site. These results indicate the potential of this assay as an indicator of phosphorus exposure in a coral reef environment.
\end{abstract}

KEY WORDS: Alkaline phosphatase $\cdot$ Acid phosphatase $\cdot$ Nutrient deficiency $\cdot$ Symbiosis $\cdot$ Aiptasia Montastraea $\cdot$ Symbiodinium

\section{INTRODUCTION}

Alkaline phosphatase activity (APA) has been used as an indicator of phosphorus deficiency in a wide range of marine plants. APA hydrolyzes organic phosphorus compounds resulting in the liberation of inorganic phosphate $\left(\mathrm{P}_{\mathrm{i}}\right)$ and an alcohol moiety (reviewed in Feder 1973). This provides a means of regenerating $\mathrm{P}_{\mathrm{i}}$ for marine plants in a $\mathrm{P}_{\mathrm{i}}$-deficient environment. There is an inverse relationship between environmental $\mathrm{P}_{\mathrm{i}}$ and APA which is the basis for using phosphatase activity as an indicator of phosphorus deficiency. APA assays were first applied to intact marine algae by

${ }^{*}$ Present address: Darling Marine Center, University of Maine, 193 Clark's Cove Road, Walpole, Maine 04573, USA. Email: eric.annis@umit.maine.edu
Kuenzler \& Perras (1965). They demonstrated that APA in cultured marine algae increases as the algae become phosphorus-deficient, but is repressed in media containing ample $\mathrm{P}_{\mathrm{i}}$. These results were further supported by the work of Fitzgerald \& Nelson (1966), which indicated that APA in freshwater phytoplankton was elevated 25 -fold in response to phosphorus deficiency. Ecological studies involving APA (Fitzgerald \& Nelson 1966, Reichhart et al. 1967, Berman 1970, Wynne 1981, Rivkin \& Swift 1982, Jansson et al. 1988, Berman et al. 1990) have shown that natural assemblages of phytoplankton exhibit similar responses to phosphorus deficiency. APA assays have also been applied as indicators of phosphorus deficiency in a variety of marine plants, including cyanobacteria (Yentsch et al. 1972), marine diatoms (Möller et al. 1975), sea grasses (Short et al. 1985, Perez \& Romero 1993) and benthic algae (Lapointe 1987, Lapointe \& 
O'Connell 1989). All of these studies indicate that phosphatases are repressible enzymes expressed in response to low environmental $P_{i}$.

In this paper, we apply an APA assay to zooxanthellae symbiotic with sea anemones and reef corals to address the question of phosphate exposure in coral reef environments. Reef-building corals thrive in oligotrophic tropical waters, and elevated nutrient levels may have deleterious effects on corals that include light limitation by phytoplankton blooms, increased competition from otherwise nutrient limited benthic macroalgae (Johannes 1975, Bell 1992, Lapointe \& Clark 1992, but see Hughes et al. 1999), and sub-lethal impacts on growth and reproduction (Marubini \& Davies 1996, Koop et al. 2001). Using zooxanthellae as biological indicators of environmental nutrients has the advantage of integrating nutrient exposure over time to include fluctuations and episodic events that might be missed when using conventional nutrient analysis (Cook et al. 1997). The nutrient status of these algae has been assessed by indices such as elemental ratios, internal amino acid pools and ammonium enhancement of dark carbon fixation. However, these techniques have been used largely to assess nitrogen status rather than phosphorus, and have received only limited use in the field.

In corals and sea anemones, zooxanthellae occur in individual membrane-bound vacuoles (symbiosomes or perialgal vacuoles) within the endodermal cells of the host. Thus, exogenous nutrients must pass through at least 2 animal membranes before being assimilated by the algae. Despite these barriers to the external environment, uptake of $\mathrm{P}_{\mathrm{i}}$ has been observed in corals and sea anemones, and is dependent upon the presence of zooxanthellae (Yonge \& Nicholls 1931, D'Elia \& Webb 1977, Jackson \& Yellowlees 1990, Muller-Parker et al. 1990).

The development of an APA assay for zooxanthellae also provides an opportunity to examine phosphorus interactions between the host and symbiont. Cook \& D'Elia (1987) as well as Miller \& Yellowlees (1989) proposed that cnidarian hosts use nutrient limitation to control the growth of symbiotic zooxanthellae populations. Nitrogen has been suggested as limiting the growth of zooxanthellae in several corals (HoeghGuldberg \& Smith 1989, Muscatine et al. 1989, MullerParker et al. 1994), but there is evidence for P-limitation of zooxanthellae in the coral Acropora formosa (Jackson et al. 1989, Jackson \& Yellowlees 1990). Jackson et al. (1989) isolated 2 acid phosphatases from the zooxanthellae in $A$. formosa and demonstrated the repressibility of these enzymes in freshly isolated zooxanthellae. The nutrient status of Symbiodinium bermudense in symbiosis with the sea anemone Aiptasia pallida has not been determined with respect to phos- phorus. Zooxanthellae from well-fed and field-collected A. pallida were nitrogen-sufficient, but became Nlimited when the host was starved (Cook et al. 1997). Increased uptake rates of $\mathrm{P}_{\mathrm{i}}$ by symbiotic $A$. pallida during starvation (Muller-Parker et al. 1990) indicated P-limitation, but the P-status of zooxanthellae was not examined.

Here, we demonstrate that Symbiodinium bermudense becomes P-limited with starvation of the host and exhibits APA levels which reflect $P_{i}$ levels in the ambient seawater. We also report significant differences in the APA of zooxanthellae from the coral Montastraea faveolata that reflect ambient $\mathrm{P}_{\mathrm{i}}$ levels in situ. These results suggest that APA may be a useful indicator of environmental $P_{i}$ exposure in coral reef environments.

\section{MATERIALS AND METHODS}

Organisms. The sea anemone Aiptasia pallida and its dinoflagellate symbiont Symbiodinium bermudense (Banaszak et al. 1993) were obtained from a clonal culture of A. pallida originally collected from Walsingham Pond, Bermuda (Cook et al. 1988). The symbiont was originally isolated from the host and cultured by G. Muller-Parker in 1984 (pers. comm.). Both the anemones and the cultured zooxanthellae (CZ) were maintained in an incubator at $25^{\circ} \mathrm{C}$ with a $12: 12 \mathrm{~h}$ light:dark photoperiod (illumination $\sim 70 \mu \mathrm{mol} \mathrm{m} \mathrm{m}^{-2} \mathrm{~s}^{-1}$ ). The anemones were fed freshly hatched Artemia spp. daily for at least $5 \mathrm{~d}$ prior to use. CZ had been maintained in batch culture with Provasoli's ES medium (Provasoli 1968) since their initial isolation. For this work, a modified ES medium was used with an inorganic source of phosphate $\left(\left[\mathrm{NaH}_{2} \mathrm{PO}_{4}\right]_{\text {final }}=56 \mu \mathrm{M}\right)$ in place of the standard organic phosphorus source ( $\beta$-glycerophosphate). Cultures were inoculated with sterile technique, using acid-washed, autoclaved glassware and autoclaved filtered $(0.22 \mu \mathrm{m})$ seawater.

The field component of this work utilized zooxanthellae (Symbiodinium sp.) from the coral Montastraea faveolata. Corals were collected from 2 sites: the 'Coral Gardens' located approximately $1.5 \mathrm{~km}$ from shore on the south side of Lower Matecumbe Key, and 'Bock Cay' near Lee Stocking Island in the Bahamas. All coral colonies were located in 1 to $3 \mathrm{~m}$ of water, and coral samples were obtained by chiseling off 10 to $25 \mathrm{~cm}^{2}$ pieces from the skirt of colonies. The Bahamian corals were collected under a CITES permit issued to C.B.C. Florida Keys corals were collected under federal (FKNMS-225-97) and state (Florida 96S-046) permits issued to C.B.C.

Isolation of zooxanthellae. Freshly isolated zooxanthellae (FIZ) were obtained from Aiptasia pallida and Montastraea faveolata through homogenization of ani- 
mal tissues, and separation of zooxanthellae through repeated centrifugation and suspension in seawater (Johannes \& Wiebe 1970). CZ in late log phase growth ( 2 to $9 \times 10^{5} \mathrm{cells} \mathrm{ml}^{-1}$ ) were isolated from their culture medium by centrifugation and were resuspended in seawater. Gulf Stream filtered $(0.22 \mu \mathrm{m})$ seawater (GSFSW) was used in these preparations and had a background concentration of soluble reactive phosphorus below the level of detection for our assay $\left(<0.030 \mu M_{i}\right.$ Strickland \& Parsons 1972). Final suspensions of algae from the 3 different sources were made up to concentrations between 5 and $10 \times 10^{5} \mathrm{cells} \mathrm{ml}^{-1}$ for phosphatase assays, and aliquots were frozen for subsequent cell counts.

Assay of phosphatase activity. The working parameters for the assay of phosphatase activity in suspensions of zooxanthellae were developed in preliminary studies (Annis 1998). Phosphatase activity was determined using a colorimetric assay modified from that of Kuenzler \& Perras (1965), using para-nitrophenyl phosphate ( $p$-NPP) as a substrate which yields the yellow hydrolysis product, para-nitrophenol ( $p$-NP). The incubation solution consisted of $500 \mu \mathrm{l}$ cell suspension (as above), $500 \mu \mathrm{l} p$-NPP stock solution (7.6 mM p-NPP in GSFSW) and $50 \mu \mathrm{l}$ Tris buffer solution (1.0 M prepared in GSFSW). Incubations were conducted in darkness at $25^{\circ} \mathrm{C}$ for 2 to $5 \mathrm{~h}$ and were terminated by the addition of $200 \mu \mathrm{l} 1.0 \mathrm{~N} \mathrm{NaOH}$. Samples were centrifuged immediately after incubation to remove algal cells and precipitate formed by the addition of $\mathrm{NaOH}$. The absorbance of the supernatant was read at $410 \mathrm{~nm}$ on a spectrophotometer using $1.0 \mathrm{~cm}$ cuvettes against a blank of $500 \mu \mathrm{l}$ GSFSW, $500 \mu \mathrm{l} p$-NPP, $200 \mu \mathrm{l}$ $1.0 \mathrm{~N} \mathrm{NaOH}$ and $50 \mu \mathrm{l} 1.0 \mathrm{M}$ Tris base. The blank solution was prepared immediately prior to sample reading. Three background samples were run with each incubation using $500 \mu \mathrm{l}$ GSFSW in place of the algal suspension to account for non-enzymatic decomposition of the substrate and any sources of phosphatase activity present in the GSFSW. The average value of the background replicates was subtracted from sample readings before enzyme activity was calculated. A standard curve for absorbance of the reaction product was established by linear regression (absorbance $=$ $\left.0.159[p-\mathrm{NP}]+0.0005, \mathrm{R}^{2}=0.9998\right)$ using known concentrations of ACS reagent grade $p$-NP in samples containing $1000 \mu \mathrm{l} \mathrm{GSFSW}, 50 \mu \mathrm{l} 1.0 \mathrm{M}$ Tris base and $200 \mu \mathrm{l} 1.0 \mathrm{~N} \mathrm{NaOH}$. Enzyme activity was expressed in units of fmol $p$-NP released cell ${ }^{-1} \mathrm{~h}^{-1}$.

Biomass determinations. Total zooxanthellae per anemone was calculated from cell counts of the initial anemone homogenate. Aliquots were frozen at the time of isolation, and cell counts were performed on a hemocytometer and diluted 2- or 4-fold with GSFSW as needed. Total zooxanthellae were reported as
$10^{6}$ cells anemone ${ }^{-1}$. Symbiont density (algal cells mg protein $^{-1}$ ) was also calculated to compensate for natural variation in the size of anemones. Anemone protein was assayed using the combined supernatants from the first 2 rinses of the algal pellet. Three $1.0 \mathrm{ml}$ aliquots were taken for protein assays. Protein content (mg protein anemone ${ }^{-1}$ ) was determined for each aliquot by the Hartree modification of the Lowry procedure (Hartree 1972).

pH optima of phosphatases of Symbiodinium bermudense. To determine the optimal $\mathrm{pH}$ for the phosphatases of zooxanthellae in culture and in symbiosis, $\mathrm{CZ}$ and FIZ were assayed for phosphatase activity over a range of $\mathrm{pH}$ values between 4.0 and 11.0. Assay solutions with $\mathrm{pH}$ values of 4.0, 5.0 and 6.0 were prepared using a $1.0 \mathrm{M}$ stock solution of citrate buffer (prepared after Gomori 1975). To obtain $\mathrm{pH} 7.0,8.0$ and 9.0, 1.0 M Tris buffer was titrated with $6 \mathrm{~N} \mathrm{HCl}$, while a $1.0 \mathrm{M}$ carbonate/bicarbonate buffer (Gomori 1975) was titrated with $6 \mathrm{~N} \mathrm{NaOH}$ to yield $\mathrm{pH} 10.0$ and 11.0. All buffer solutions were prepared in GSFSW, and $50 \mu \mathrm{l}$ of each was added to the incubation solution in place of the regular Tris base to yield final buffer concentrations of $\sim 0.05 \mathrm{M}$. Three cultures of algae and 3 preparations of FIZ from Aiptasia pallida were assayed over this $\mathrm{pH}$ range, using an incubation time of $4.0 \mathrm{~h}$.

Effect of exogenous $P_{i}$ on APA of Symbiodinium bermudense. Cultured zooxanthellae were isolated from eight $150 \mathrm{ml}$ subcultures; 4 were resuspended in a treatment medium containing ES medium with no $\mathrm{NaH}_{2} \mathrm{PO}_{4}\left(\mathrm{P}_{\mathrm{i}}\right)$, while the other 4 were resuspended in ES medium with the standard $\mathrm{P}_{\mathrm{i}}$ concentration $(56 \mu \mathrm{M})$. APA assays were conducted on these cultures immediately prior to resuspension in treatment medium (Day 0) and periodically for $25 \mathrm{~d}$ after the transfer.

To evaluate the relationship between APA of zooxanthellae in symbiosis and external $P_{i}$ levels, sea anemones from fed cultures were incubated without feeding in GSFSW with $P_{i}$ concentrations of 0.0 and $0.5 \mu \mathrm{M}$. Anemones were maintained individually in $20 \mathrm{ml}$ glass scintillation vials with $5 \mathrm{ml}$ of experimental medium at $25^{\circ} \mathrm{C}$ with a $12: 12 \mathrm{~h}$ light:dark regime, and the medium was changed every 2 to $3 \mathrm{~d}$. The incubation lasted $35 \mathrm{~d}$ with assays conducted at Days 0, 14, 21, 28 and 35. Anemones were randomly assigned a treatment and incubation period when they were initially isolated in scintillation vials. Six anemones were processed from each treatment on each sampling day. By Day 35, these unfed anemones were greatly reduced in size so that 2 anemones were combined for each sample to obtain enough algae for APA assays. Total zooxanthellae populations and anemone protein content were determined for Days 0, 14, 28 and 35.

Field-collected corals. Montastraea faveolata samples were collected from the Florida Keys and the 
Bahamas to compare APA in FIZ from corals in areas of differing ambient $\mathrm{P}_{\mathrm{i}}$ levels. The Bahamian site near Lee Stocking Island was a relatively pristine reef habitat with minimal anthropogenic nutrient influences. Bahamian corals were collected on July 29, 1997 and were processed at Lee Stocking Island. The Florida Keys site was in close proximity to a developed island and subject to tidal exchange with Florida Bay water. Corals from the Florida Keys were collected on October 20, 1997, and transported without water in plastic bags to Harbor Branch Oceanographic Institution for analysis. In the Bahamas, 1 piece was collected from each of 5 colonies. In the Florida Keys, 1 piece was collected from each of 4 colonies. Assays were conducted in triplicate for each piece of coral. Unfiltered seawater samples were taken at the time of coral collection in the Bahamas, stored at $-40^{\circ} \mathrm{C}$ for $2 \mathrm{~d}$ and assayed for phosphate using the molybdate assay of Strickland \& Parsons (1977).

Statistical analysis. APA data exhibited unequal variances as determined by an $F_{\text {max }}$ test and were log-transformed prior to analysis. Biomass data did not exhibit unequal variance and were not transformed. P-limitation experiments with CZ were analyzed using ANOVA for repeated measures. APA and biomass measurements from anemones incubated in $\mathrm{P}_{\mathrm{i}}$ treatments were analyzed using a 2-way ANOVA for factors of time and treatment with a Tukey post-hoc pairwise comparison. The Day 0 samples were not included in this analysis as they had not yet been assigned to treatments. APA data from 2 anemones were discarded: one (Day 28) due to a cell counting error, and the other (Day 0) because it was identified as an outlier using a Dixon test (Sokal \& Rohlf 1995). Bio-

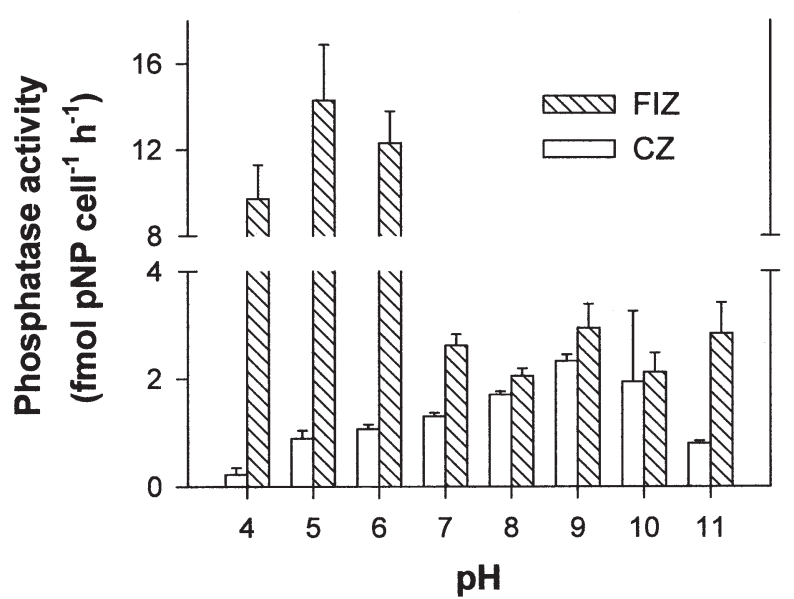

Fig. 1. Symbiodinium bermudense. The $\mathrm{pH}$-dependent phosphatase activity of cultured zooxanthellae (CZ) and freshly isolated zooxanthellae (FIZ) from well-fed Aiptasia pallida. Enzyme activity of FIZ is reported with a break in the $y$-axis to facilitate comparison of peak activity. Bars denote $\pm 1 \mathrm{SE}$ $(\mathrm{n}=3)$ mass data for each treatment were secondarily analyzed by single-factor ANOVA for changes over time with respect to the Day 0 samples. Field-collected corals were compared using a 2-sample $t$-test, assuming unequal variance.

\section{RESULTS}

\section{pH optima of phosphatase activity in Symbiodinium bermudense}

Whole cell suspensions of CZ and FIZ were tested using $\mathrm{pH}$ values from 4 to $11 \mathrm{in}$ increments of single $\mathrm{pH}$ units. The results (Fig. 1) showed that CZ phosphatase activity had a $\mathrm{pH}$ optimum of 9, while FIZ had a $\mathrm{pH}$ optimum of 5; however, phosphatase activity was higher in the FIZ at every $\mathrm{pH}$ value tested. All subsequent experiments were conducted at a $\mathrm{pH}$ of 8.1 (corresponding to the $\mathrm{pH}$ of GSFSW) and should be considered as assays for APA.

\section{Effect of exogenous $P_{i}$ on APA of Symbiodinium bermudense}

Cultured zooxanthellae provided with an ample supply of $\mathrm{NaH}_{2} \mathrm{PO}_{4}$ showed little change in APA during a 25 d exposure; APA increased by Day 3 and then remained constant for the remainder of the experiment (Fig. 2). In contrast, APA of cultures without added $\mathrm{NaH}_{2} \mathrm{PO}_{4}$ continued to increase up to Day 13, when APA levels were 3.4 times greater than those of the cultures replete with $\mathrm{P}_{\mathrm{i}}$. APA levels of the $\mathrm{P}_{\mathrm{i}}$-free cultures declined after Day 13, but always exceeded those of cultures with $\mathrm{P}_{\mathrm{i}}$. ANOVA revealed highly significant effects of time and treatment ( $p<0.001$ for both). These results indicate that APA was expressed in $\mathrm{CZ}$ in response to P-limitation.

FIZ from unfed anemones in GSFSW with 0.0 and $0.5 \mu \mathrm{M} \mathrm{NaH} \mathrm{PO}_{4}$ exhibited a slight decrease in APA during the first $3 \mathrm{wk}$ (Fig. 3). APA in both groups increased on Day 28, although the increase was 3 times greater in FIZ from anemones maintained without additional $\mathrm{P}_{\mathrm{i}}$. The high variance of APA in the $0.0 \mu \mathrm{M}$ treatment on Day 28 resulted from large increases in APA in half the anemones, while APA levels of the others remained near baseline values. APA of FIZ from these 'high APA' anemones was 15 times greater than that of the others. APA in the $0.5 \mu \mathrm{M}$ treatment subsequently returned to baseline levels on Day 35. APA in the $0.0 \mu \mathrm{M}$ treatment also declined substantially on Day 35, but remained higher than that of the group with added $\mathrm{P}_{\mathrm{i}}$. Two-way ANOVA revealed significant effects both of time $(p<0.001)$ and treatment $(p<0.05)$. 


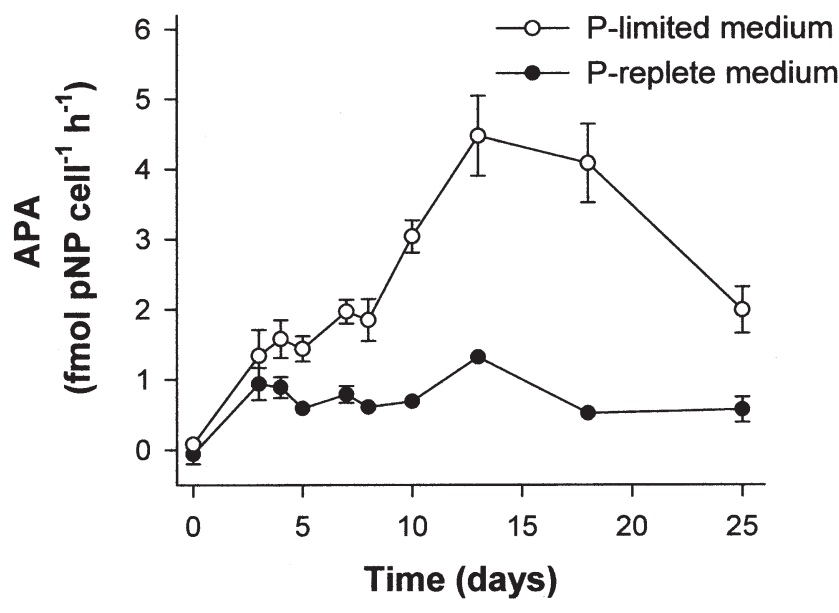

Fig. 2. Symbiodinium bermudense. Alkaline phosphatase activity (APA) levels of cultured zooxanthellae (CZ) in response to P-limitation. CZ were maintained in ES media with initial $\mathrm{PO}_{4}$ concentrations of $0 \mu \mathrm{M}$ (P-limited) and $56 \mu \mathrm{M}$ (P-replete). Bars denote \pm 1 SE $(\mathrm{n}=4)$

\section{Biomass measurements}

The total number of zooxanthellae in anemones maintained without food or added $\mathrm{P}_{\mathrm{i}}$ decreased steadily during the $5 \mathrm{wk}$ of the experiment (Fig. 4A). In contrast, the total number of zooxanthellae in the anemones kept in $0.5 \mu \mathrm{M} \mathrm{P}_{\mathrm{i}}$ increased slightly during the first $14 \mathrm{~d}$, then slowly decreased to just below the initial population level. After $35 \mathrm{~d}$, these anemones contained more than 10 times as many symbionts as those without added $\mathrm{P}_{\mathrm{i}}$. Two-way ANOVA revealed highly significant effects of time $(p<0.01)$ and treatment $(p<0.001)$. Single-factor ANOVA showed a significant reduction of zooxanthellae populations over time in the $0.0 \mu \mathrm{M}$ treatment $(\mathrm{p}<0.01)$, while there was no significant change in the $0.5 \mu \mathrm{M}$ treatment ( $p>0.05$ ) over the $5 \mathrm{wk}$ period.

Host protein declined in both treatments during the experiment (Fig. 4B), but 2-way ANOVA indicated no overall effect of either time or treatment ( $p>0.05$ for both). During the first $2 \mathrm{wk}_{\text {, the density }}$ of zooxanthellae (algal cells per mg host protein) increased 1.6-fold in the $0.5 \mu \mathrm{M}$ anemones and 1.4fold in the $0.0 \mu \mathrm{M}$ anemones (Fig. 4C). After the first $2 \mathrm{wk}$, zooxanthellae density in the $0.0 \mu \mathrm{M}$ treatment declined steadily. Two-way ANOVA showed a significant effect of treatment $(\mathrm{p}<0.01)$ and time $(\mathrm{p}<$ 0.05). The results of a single-factor ANOVA on each treatment over time show that the ratio of zooxanthellae to anemone protein decreased significantly in the $0.0 \mu \mathrm{M}$ treatment $(\mathrm{p}<0.05)$, but did not change significantly in the $0.5 \mu \mathrm{M}$ treatment $(\mathrm{p}>$ 0.05).

\section{Field-collected corals}

Zooxanthellae from the Lee Stocking Island corals had APA levels 3.3 times higher than zooxanthellae from the Florida corals (Fig. 5). The difference in APA between the sites was highly significant $(p<0.01$, $t=5.223$, df $=5$ ). Analysis of water samples from the Lee Stocking Island site at the time of collection indicated that the average soluble reactive phosphorus concentration was $0.018 \mu \mathrm{M}$. This is below the $0.030 \mu \mathrm{M}$ lower limit of detection for the molybdate assay (Strickland \& Parsons 1972). One sample was discarded due to probable phosphorus contamination. Water samples were not taken at the time of collection at the Florida Keys site, but we recorded values ranging between 0.08 and $0.23 \mu \mathrm{M}$ from this site during the previous year (Cook et al. 2002). Szmant \& Forrester (1996) reported a mean soluble reactive phosphorus concentration of $0.17 \mu \mathrm{M}$ near the collection site. Thus, it is likely that corals from the Florida Keys were exposed to higher concentrations of $\mathrm{P}_{\mathrm{i}}$.

\section{DISCUSSION}

\section{pH optima of phosphatases in Symbiodinium bermudense}

Our results indicate the presence of both acid (AcPA) and alkaline (APA) phosphatases in cell suspensions of Symbiodinium bermudense. The phosphatase activity of FIZ from Aiptasia pallida was predominantly acidic, while the activity in CZ was predominantly alkaline,

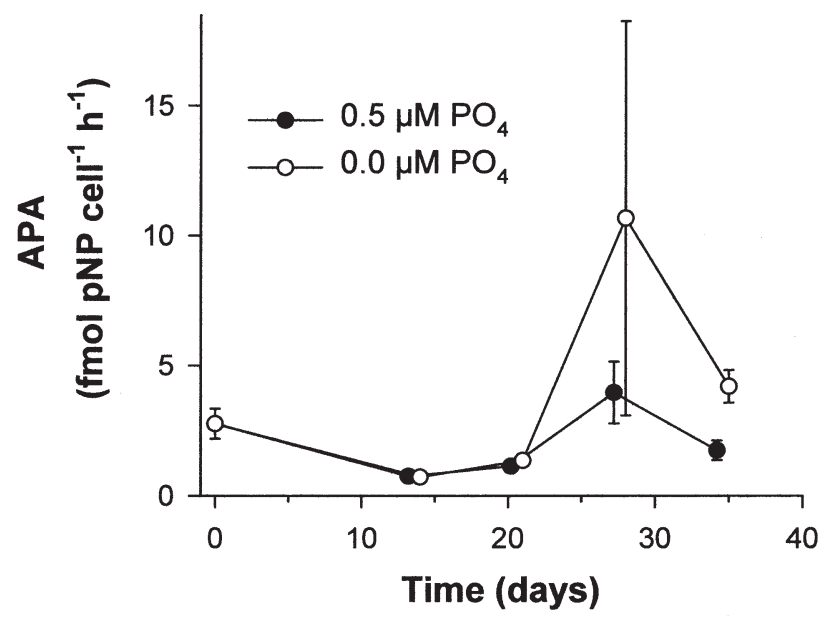

Fig. 3. Symbiodinium bermudense. Alkaline phosphatase activity (APA) levels of freshly isolated zooxanthellae from Aiptasia pallida incubated in seawater containing 0.0 or $0.5 \mu \mathrm{M}$ $\mathrm{PO}_{4}$. The $t_{0}$ point is data from 5 anemones which were maintained in unenriched seawater and fed daily. Bars denote \pm 1 SE $(n=6)$ 


\section{A: Zooxanthellae per anemone}

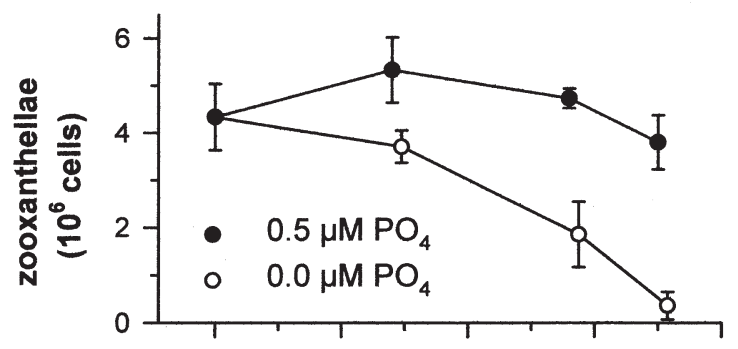

B: Total protein per anemone

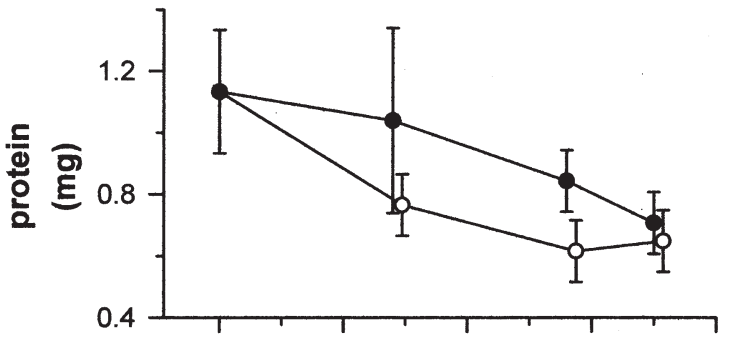

C: Zooxanthellae:protein

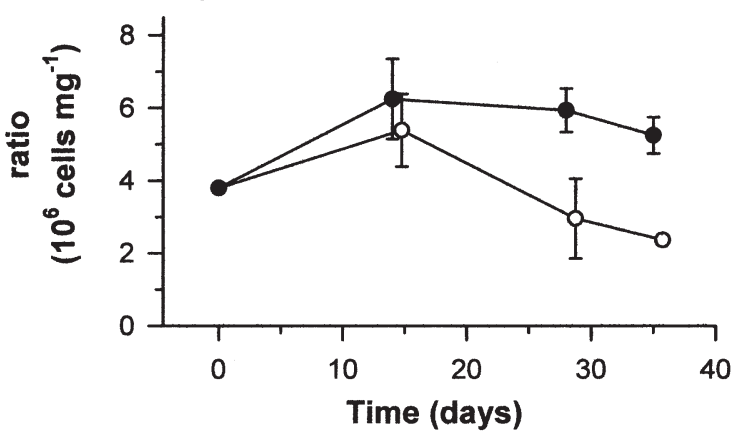

Fig. 4. Aiptasia pallida. Biomass parameters during a $35 \mathrm{~d}$ exposure to $\mathrm{PO}_{4}$-enriched seawater without feeding. $\mathrm{PO}_{4}$ concentrations were 0.0 and $0.5 \mu \mathrm{M}$. The $t_{0}$ data were collected from 6 anemones maintained in unenriched seawater with daily feeding, and are representative of the initial populations and protein content. (A) Total zooxanthellae population per anemone is expressed in $10^{6}$ cells. (B) Total protein per anemone reported in $\mu \mathrm{g}$. (C) The ratio of zooxanthellae to host protein expressed as cells $\mu \mathrm{g}$ protein ${ }^{-1}$. Symbols as in Fig. 3. Data points have been slightly shifted in the $x$-axis to prevent overlap. Bars denote $\pm 1 \mathrm{SE}(\mathrm{n}=6)$

with little activity at acidic pH (Fig. 1). Jackson et al. (1989) reported that phosphatase activity in cell-free extracts of FIZ from the coral Acropora formosa at $\mathrm{pH} 5$ was 20 times greater than at $\mathrm{pH} 8$. However, it is not clear from their study if this activity resulted from surface or internal enzymes. Since we used intact cells for our study, we believe that the bulk of our activity was from surface enzymes. The presence of both AcPA and APA has been reported in cell suspensions of marine phytoplankton (Kuenzler \& Perras 1965, Aaronson \&
Patri 1976), but it is intriguing that $S$. bermudense appears to express predominately one or the other. We suggest that this is a function of the $\mathrm{pH}$ environment in which the algae are maintained, depending on whether the algae are grown in the host or in culture. The $\mathrm{pH}$ inside the perialgal vacuole is not known, but histochemical evidence suggests that the environment is mildly acidic (Jackson et al. 1989, Rands et al. 1993). Jackson et al. (1989) made a similar suggestion based on their finding of AcPA in FIZ. By contrast, the CZ in our study were maintained in a mildly alkaline seawater medium with a $\mathrm{pH}$ of between 7.8 and 8.0. Thus, it appears that $S$. bermudense can express either AcPA or APA in response to ambient $\mathrm{pH}$ levels.

The $\mathrm{pH}$ of coral tissues exhibit a strong diel pattern resulting from the photosynthetic activity of their symbiotic zooxanthellae (Fitt et al. 1995, Kühl et al. 1995). This raises the possibility that expression of APA and AcPA may alternate with diel changes in tissue $\mathrm{pH}$. Although we did not test this hypothesis explicitly, data were collected from anemones held in light or dark depending on the time of day the assays were run. In the P-incubated anemone experiment (Fig. 3), Day 14 anemones were processed during daylight hours, while Day 21 anemones were processed at night. A Tukey post-hoc pairwise comparison showed no significant difference in APA in either treatment between these 2 days $(n=6, p=0.71$ for the $0.0 \mu \mathrm{M}$ treatment and $\mathrm{p}=0.97$ for the $0.5 \mu \mathrm{M}$ treatment). This suggests that the APA levels probably fluctuate on time scales longer than the daily $\mathrm{pH}$ cycles.

\section{Effect of $P_{i}$ availability on APA of zooxanthellae in culture and in symbiosis}

The results of P-limitation experiments with $\mathrm{CZ}$ demonstrated that APA is elevated in P-limited cultures as in other microalgae (Kuenzler \& Perras 1965). Jackson et al. (1989) studied the effect of $P_{i}$ on AcPA of Symbiodinium kawagutii cultured from the coral Montipora verrucosa. They found a similar temporal pattern of expression in P-limited cells as we did with cultured Symbiodinium bermudense: a lag period followed by an increase in activity and then a return to lower levels. The elevation of APA in CZ in response to low levels of exogenous $P_{i}$ provides the basis for using APA as an indicator of phosphorus sufficiency in zooxanthellae.

Assays of APA in FIZ from Aiptasia pallida showed that activity increased significantly in response to starvation of the host and that this effect was heightened by the absence of $P_{i}$ in the ambient water (Fig. 3). It appears that in the absence of host feeding, zooxanthellae in both treatments became phosphorus- 
deficient and expressed APA. The zooxanthellae from the $0.0 \mu \mathrm{M}$ treatment experienced the combined effect of host starvation and minimal ambient $\mathrm{P}_{\mathrm{i}}$. Accordingly, they were more P-deficient than those in the $0.5 \mu \mathrm{M}$ treatment and responded with higher levels of APA. Lower APA levels in the $0.5 \mu \mathrm{M}$ treatment indicate that the zooxanthellae were able to utilize the exogenous phosphorus, resulting in reduced P-deficiency. In a broader context, this establishes a relationship between APA of symbiotic zooxanthellae and $P_{i}$ levels outside the host, which is fundamental to the use of APA as a biological indicator of environmental $\mathrm{P}_{\mathrm{i}}$. As with $\mathrm{P}_{\mathrm{i}}$ fluxes in symbiotic $A$. pallida (MullerParker et al. 1990), symbiont APA most likely reflects $\mathrm{P}_{\mathrm{i}}$ levels in host tissue, which depend upon both exogenous $\mathrm{P}_{\mathrm{i}}$ and host feeding. The $\mathrm{P}_{\mathrm{i}}$ levels in the host tissue may also affect the timing of peak APA. We note that CZ exhibited peak APA $13 \mathrm{~d}$ after the removal of $P_{i}$ from the medium, while zooxanthellae in symbiosis did not reach peak APA until $28 \mathrm{~d}$ of starvation. Zooxanthellae also exhibit higher growth rates in culture than in symbiosis (Cook \& D'Elia 1987, Cook et al. 1997, Smith \& Muscatine 1999). This may result in faster depletion of $\mathrm{P}_{\mathrm{i}}$ in $\mathrm{CZ}$, and earlier onset of $\mathrm{P}$ deficiency and elevation of APA.

The major difference between zooxanthellae from anemones in the $2 \mathrm{P}_{\mathrm{i}}$ treatment groups was observed on Days 28 and 35, when FIZ from anemones without added $\mathrm{P}_{\mathrm{i}}$ had higher APA. The high variance observed in this group probably resulted from using a fixed $7 \mathrm{~d}$ interval to assess a brief and variable period of elevated APA. We speculate that those FIZ in the $0.0 \mu \mathrm{M}$ treatment with low activity on Day 28 had already passed the period of peak activity or had not yet

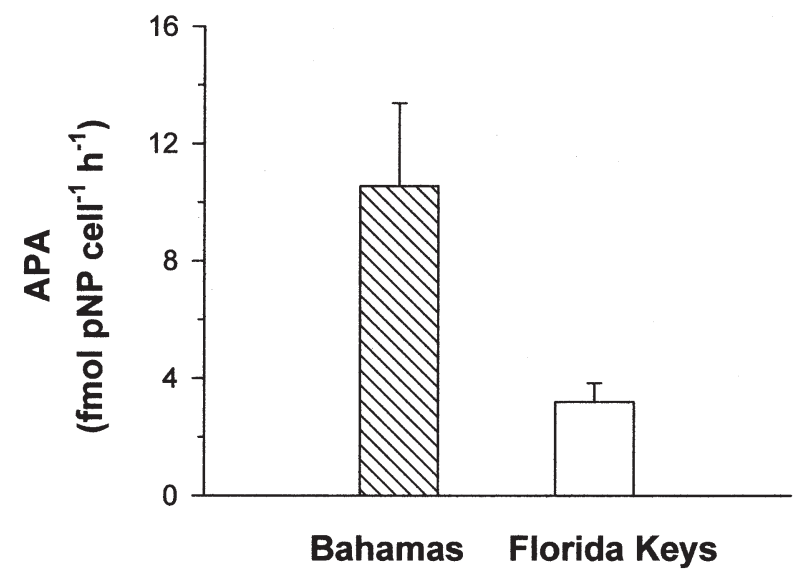

Fig. 5. Symbiodinium spp. Comparison of phosphatase activity in freshly isolated zooxanthellae from Montastraea faveolata collected from the Bahamas and Florida Keys. Bars denote \pm 1 SE $(n=5$ for Bahamian corals and $n=4$ for Florida corals) increased APA, and we suggest this reflects initial differences in host or algal reserves between anemones. In both CZ and FIZ, APA was turned on in P-limited cells but declined substantially after reaching peak values. The reason for this decline in APA is not known. It may reflect the attainment of sufficient $P_{i}$ levels through APA, repression of APA in the absence of available substrate, or a general decline in metabolism.

\section{Biomass parameters from anemones exposed to elevated $P_{i}$}

This is the first study to demonstrate that the reduction of zooxanthellae density typically associated with starvation of the host may be countered by elevated exogenous $\mathrm{P}_{\mathrm{i}}$. Anemones exposed to $0.5 \mu \mathrm{M} \mathrm{P}_{\mathrm{i}}$ maintained higher symbiont density than those in the $0.0 \mu \mathrm{M} \mathrm{P}_{\mathrm{i}}$ treatment throughout the experiment. Anemones in the $0.5 \mu \mathrm{M}$ treatment experienced a 1.6-fold increase in zooxanthellae density that remained elevated for the remainder of the experiment, while density in anemones without $\mathrm{P}_{\mathrm{i}}$ declined after Day 14 (Fig. 4C). These results indicate that Symbiodinium bermudense becomes P-limited in unfed Aiptasia pallida and that it is able to utilize exogenous sources of $\mathrm{P}_{\mathrm{i}}$. These results are consistent with increases in zooxanthellae density in response to elevated exogenous $\mathrm{P}_{\mathrm{i}}$ observed in several coral species during the ENCORE experiments on the Great Barrier Reef (Koop et al. 2001). In contrast, $2 \mu \mathrm{M} \mathrm{P}_{\mathrm{i}}$ had no effect on the symbiont density of the coral Stylophora pistillata (Muscatine et al. 1989), and densities and growth rates of the dinoflagellate symbionts of the hydroid Myrionema amboinense declined at this concentration (Fitt \& Cook 2001). The addition of $60 \mu \mathrm{M} \mathrm{P} \mathrm{P}_{\mathrm{i}}$ had no effect on zooxanthellae densities in unfed Aiptasia pulchella (Smith \& Muscatine 1999). The reasons for these differences are not clear, but may involve genetic differences between the symbionts, or that high initial $\mathrm{P}_{\mathrm{i}}$ concentrations $(3.5$ to $5.0 \mu \mathrm{M})$ in the artificial seawater used in the latter study provided sufficient levels of $\mathrm{P}_{\mathrm{i}}$.

Zooxanthellae in symbiosis derive phosphorus from host feeding, host metabolites and ambient water (Johannes et al. 1970, D'Elia 1977, Muscatine \& Porter 1977, Cates \& McLaughlin 1979). Accordingly, starvation of the host removes a potential source of nutrients for the algae. Aiptasia pallida typically responds to starvation with a reduction in the symbiont population (Clayton \& Lasker 1984, Cook et al. 1988), and zooxanthellae populations in our $0.0 \mu \mathrm{M}$ treatment anemones declined steadily throughout the incubation. The presence of elevated $P_{i}$ levels in the ambient water offset the effects of host starvation, and anemones in 
the $0.5 \mu \mathrm{M}$ treatment exhibited no net loss of zooxanthellae during the $35 \mathrm{~d}$ incubation period. The maintenance of zooxanthellae populations in this treatment is remarkable given the loss of nearly $40 \%$ of the host's protein biomass over the course of the experiment.

Host protein content declined in both treatments as a result of starvation, and it was evident by Day 35 that the anemones in both groups were reduced in size. There were no differences between the treatments, but the loss of host protein appeared to be more gradual in the $0.5 \mu \mathrm{M}$ treatment. This may have resulted from symbiont contribution to host metabolism. When reserves of carbohydrate and lipid are exhausted, unfed anemones resort to protein catabolism to support metabolic functions (Fitt \& Pardy 1981). Under starvation conditions, photosynthates translocated from the zooxanthellae to the host provide an alternate source of energy and reduce catabolism of host proteins (Szmant et al. 1990). Anemones in the $0.5 \mu \mathrm{M}$ treatment maintained larger zooxanthellae populations and exhibited a more gradual loss of protein. These results are consistent with the results of Fitt \& Pardy (1981), who demonstrated that the presence of symbiotic zooxanthellae enhanced the survival of unfed anemones.

\section{Field-collected corals}

APA of FIZ from Montastraea faveolata was more than 3 times higher in Bahamas samples than in those from the Florida Keys, indicating that zooxanthellae in Bahamas corals were more P-limited than zooxanthellae in Florida Keys corals. This corresponded to what was likely a 5-fold difference in the ambient $\mathrm{P}_{\mathrm{i}}$ level between sites. While our field data are preliminary, they indicate that APA levels do reflect environmental $P_{i}$ levels and demonstrate the potential for using this APA assay as an indicator of $\mathrm{P}_{\mathrm{i}}$ exposure of reef corals. The use of intact algae rather than a purified enzyme makes this a relatively simple and convenient assay. Additionally, the methodology circumvents some of the confounding factors commonly associated with phosphatase assays of natural phytoplankton populations. Populations of zooxanthellae in a single coral host may be maintained with minimal spatial and temporal variation, although the genetic composition of populations within a host may vary (Rowan et al. 1997). Thus, the relatively long-term association of zooxanthellae with a cnidarian host essentially integrates $\mathrm{P}_{\mathrm{i}}$ exposure over time. Extrapolations from our laboratory experiments with unfed Aiptasia pallida suggest that the APA in field samples might integrate $\mathrm{P}_{\mathrm{i}}$ exposure over a period of 1 to 2 mo. This provides an alternative to APA levels that fluctuate on the scale of days to weeks in benthic algae and phytoplankton (Kuenzler \& Perras 1965, Weich \& Graneli 1989, Urnezis 1995). Potentially, this assay would provide a means of monitoring long-term changes in $\mathrm{P}_{\mathrm{i}}$ in a coral reef environment. The integration of APA response over time would allow bimonthly or quarterly sampling to determine shifts in $\mathrm{P}_{\mathrm{i}}$ exposure, resulting from seasonal changes or prolonged anthropogenic impacts. Clearly, additional research is needed to establish the efficacy of this assay in the field. Future work should address regional differences in APA expression, and examine local effects of environmental parameters such as turbidity, irradiance, temperature and depth with respect to APA expression. Most importantly, local baseline APA values need to be established and correlated with ambient $\mathrm{PO}_{4}$ levels. Developing a more complete understanding of this relationship in the field will allow the assay of APA in zooxanthellae to be used effectively as a biological indicator of $\mathrm{P}_{\mathrm{i}}$ exposure in the coral reef environment.

Acknowledgements. We thank Drs. G. N. Wells and I. W. Duedall for their critical review of this project, and Dr. E. M. Mueller for assistance in coral collections. We are grateful to L. Hrdlicka, E. C. Fisher, C. Bartell and D. Davis for assistance in the field and lab. We also thank 4 anonymous reviewers for their constructive comments on this manuscript. This research was funded by the US EPA Region IV Special Studies of the Florida Keys National Marine Sanctuary Water Quality Protection Program, ONR grant N00014-96-1-0602, and grant no. CMRC-97-7108 from the Caribbean Marine Research Center to C.B.C. This work is Contribution No. 1481 of Harbor Branch Oceanographic Institution.

\section{LITERATURE CITED}

Aaronson S, Patri NJ (1976) The role of surface and extracellular phosphatases in the phosphorus requirement of Ochromonas. Limnol Oceanogr 21:838-845

Annis ER (1998) Phosphatase activity in the zooxanthellae from the sea anemone Aiptasia pallida. MSc thesis, Florida Institute of Technology, Melbourne, FL

Banaszak AT, Iglesias-Prieto R, Trench RK (1993) Scrippsiella velellae sp. nov. (Peridiniales) and Gloeodinium viscum sp. nov. (Phytodiniales), dinoflagellate symbionts of two hydrozoans (Cnidaria). J Phycol 29:517-528

Bell PRF (1992) Eutrophication and coral reefs - some examples in the Great Barrier Reef lagoon. Water Res 26:553-568

Berman T (1970) Alkaline phosphatases and phosphorus availability in Lake Kinneret. Limnol Oceanogr 15:663-674

Berman T, Wynne D, Kaplan B (1990) Phosphatases revisited: analysis of particle-associated enzyme activities in aquatic systems. Hydrobiologia 207:287-294

Cates N, McLaughlin JJA (1979) Nutrient availability for zooxanthellae derived from physiological activities of Condylactus spp. J Exp Mar Biol Ecol 37:31-41

Clayton WS Jr, Lasker HR (1984) Host feeding regime and zooxanthellal photosynthesis in the anemone, Aiptasia pallida (Verrill). Biol Bull 167:590-600 
Cook CB, D'Elia CF (1987) Are zooxanthellae ever nutrientlimited? Symbiosis 4:199-212

Cook CB, D'Elia CF, Muller-Parker G (1988) Host feeding and nutrient sufficiency for zooxanthellae in the sea anemone Aiptasia pallida. Mar Biol 98:253-262

Cook CB, Muller-Parker G, Ferrier MD (1997) An assessment of indices of nutrient sufficiency in symbiotic dinoflagellates. Proc 8th Int Coral Reef Symp, Panama, 1:903-908

Cook CB, Mueller EM, Ferrier MD, Annis E (2002) Influence of nearshore waters on the corals of the Florida reef tract. In: Porter JW, Porter KG (eds) The Everglades, Florida Bay, and coral reefs of the Florida Keys: an ecosystem sourcebook. CRC Press, Boca Raton, FL, p 771-788

D'Elia CF (1977) The uptake and release of dissolved phosphorus by reef corals. Limnol Oceanogr 22:301-315

D'Elia CF, Webb KL (1977) The dissolved nitrogen flux of reef corals. Proc 3rd Int Coral Reef Symp 1:325-330

Feder J (1973) The phosphatases. Wiley-Liss, New York

Fitt WK, Cook CB (2001) The effects of feeding or addition of dissolved inorganic nutrients in maintaining the symbiosis between dinoflagellates and a tropical marine cnidarian. Mar Biol 139:507-517

Fitt WK, Pardy RL (1981) Effects of starvation, and light and dark on the energy metabolism of symbiotic and aposymbiotic sea anemones, Anthopleura elegantissima. Mar Biol 61:199-205

Fitt WK, Rees TAV, Yellowlees D (1995) Relationship between $\mathrm{pH}$ and the availability of dissolved inorganic nitrogen in the zooxanthella-giant clam symbiosis. Limnol Oceanogr 40:976-982

Fitzgerald GP, Nelson TC (1966) Extractive and enzymatic analyses for limiting or surplus phosphorus in algae. J Phycol 2:32-37

Gomori G (1975) Preparation of buffers for use in enzyme studies. In: Fasman GD (ed) Handbook of biochemistry and molecular biology, Vol VI. CRC Press, Boca Raton, FL, p 370-377

Hartree EF (1972) Determination of protein: a modification of the Lowry method that gives a linear photometric response. Anal Biochem 48:422-427

Hoegh-Guldberg O, Smith GJ (1989) Influence of the population density of zooxanthellae and supply of ammonium on the biomass and metabolic characteristics of the reef corals Seriatopora hystrix and Stylophora pistillata. Mar Ecol Prog Ser 57:173-186

Hughes T, Szmant A, Steneck R, Carpenter R, Miller S (1999) Algal blooms on coral reefs: what are the causes? Limnol Oceanogr 44:1583-1586

Jackson AE, Yellowlees D (1990) Phosphate uptake by zooxanthellae isolated from corals. Proc R Soc Lond Ser B 242: 201-204

Jackson AE, Miller DJ, Yellowlees D (1989) Phosphorus metabolism in the coral-zooxanthellae symbiosis: characterization and possible roles of two acid phosphatases in the algal symbiont Symbiodinium sp. Proc R Soc Lond Ser B 238:193-202

Jansson M, Olsson L, Pettersson K (1988) Phosphatases: origin, characteristics and function in lakes. Hydrobiologia 170:157-175

Johannes RE (1975) Pollution and degradation of coral reef communities. In: Wood EJF, Johannes RE (eds) Tropical marine pollution. Elsevier Oceanography Series, Vol 12. Elsevier Science Publishers, New York, p 13-51

Johannes RE, Wiebe WJ (1970) A method for determination of coral tissue biomass and composition. Limnol Oceanogr 15:822-824
Johannes RE, Coles SL, Kuenzel NT (1970) The role of zooplankton in the nutrition of some scleractinian corals. Limnol Oceanogr 15:579-586

Koop K, Booth D, Broadbent A, Brodie J and 16 others (2001) ENCORE: the effect of nutrient enrichment on coral reefs. Synthesis of results and conclusions. Mar Pollut Bull 42: 91-120

Kuenzler EJ, Perras JP (1965) Phosphatases of marine algae. Biol Bull 128:271-284

Kühl M, Cohen Y, Dalsgaard T, Jørgensen BB, Revsbech PN (1995) Microenvironment and photosynthesis of zooxanthellae in scleractinian corals studied with microsensors for $\mathrm{O}_{2}, \mathrm{pH}$, and light. Mar Ecol Prog Ser 117: 159-172

Lapointe BE (1987) Phosphorus- and nitrogen-limited photosynthesis and growth of Gracilaria tikvahiae (Rhodophyceae) in the Florida Keys: and experimental field study. Mar Biol 93:561-568

Lapointe BE, Clark MW (1992) Nutrient inputs from the watershed and coastal eutrophication in the Florida Keys. Estuaries 15:465-476

Lapointe BE, O'Connell J (1989) Nutrient-enhanced growth of Cladophora prolifera in Harrington Sound, Bermuda: eutrophication of a confined, phosphorus-limited marine ecosystem. Estuar Coast Shelf Sci 28:347-360

Marubini F, Davies PS (1996) Nitrate increases zooxanthellae population density and reduces skeletogenesis in corals. Mar Biol 127:319-328

Miller DJ, Yellowlees D (1989) Inorganic nitrogen uptake by symbiotic marine cnidarians: a critical review. Proc R Soc Lond Ser B 237:109-125

Möller M, Myklested S, Haug A (1975) Alkaline and acid phosphatases of the marine diatoms Chaetoceros affinis var. Willei: (Gran) Hustedt and Skeletonema costatum (Greve.) Cleve. J Mar Biol Ecol 19:217-226

Muller-Parker G, Cook CB, D'Elia CF (1990) Feeding affects phosphate fluxes in the symbiotic sea anemone Aiptasia pallida. Mar Ecol Prog Ser 60:283-290

Muller-Parker G, McCloskey LR, Hoegh-Guldberg O, McAuley PJ (1994) The effect of ammonium enrichment on animal and algal biomass of the coral Pocillopora damicornis. Pac Sci 48:273-283

Muscatine L, Porter JW (1977) Reef corals: mutualistic symbioses adapted to nutrient-poor environments. BioScience $27: 454-459$

Muscatine L, Falkowski PG, Dubinsky Z, Cook PA, McCloskey LR (1989) The effect of external nutrient resources on the population dynamics of zooxanthellae in a reef coral. Proc R Soc Lond Ser B 236:311-324

Perez M, Romero J (1993) Preliminary data on alkaline phosphatase activity associated with Mediterranean seagrasses. Bot Mar 36:499-502

Provasoli L (1968) Media and prospects for cultivation of algae. In: Watanabe A, Hattori A (eds) Cultures and collections of algae. Japapese Society of Plant Physiologists, Tokyo, Soc Plant Physiol, Hakone, p 63-75

Rands ML, Loughman BC, Douglas AE (1993) The symbiotic interface in an alga-invertebrate symbiosis. Proc R Soc Lond Ser B 253:161-165

Reichhart W, Overbeck J, Steubing L (1967) Free dissolved enzymes in lake waters. Nature 216:1345-1347

Rivkin RB, Swift E (1982) Phosphate uptake by the oceanic dinoflagellate Pyrocystis noctiluca. J Phycol 18:113-120

Rowan R, Knowlton N, Baker A, Jara J (1997) Landscape cycle of algal symbionts creates variation in episodes of coral bleaching. Nature 388:265-269

Short FT, Davis MW, Gibson RA, Zimmermann CF (1985) Evi- 
dence for phosphorus limitation in carbonate sediments of the seagrass Syringodium filiforme. Estuar Coast Shelf Sci 20:419-430

Smith GJ, Muscatine L (1999) Cell cycle of symbiotic dinoflagellates: variation in G1 phase-duration with anemone nutritional status and macronutrient supply in the Aiptasia pulchella-Symbiodinium pulchrorum symbiosis. Mar Biol 134:405-418

Sokal RR, Rohlf JF (1995) Biometry. WH Freeman, New York

Strickland JDH, Parsons TR (1977) A practical handbook of seawater analysis, 2nd edn. Fisheries Research Board of Canada, Ottawa

Szmant AM, Forrester A (1996) Water column and sediment nitrogen and phosphorus distribution patterns in the Florida Keys, USA. Coral Reefs 15:21-41

Szmant AM, Ferrer LM, Fitzgerald LM (1990) Nitrogen excretion and $\mathrm{O}: \mathrm{N}$ ratios in reef corals: evidence for conservation of nitrogen. Mar Biol 104:119-127

Editorial responsibility: Otto Kinne (Editor),

Oldendorf/Luhe, Germany
Urnezis CM (1995) Alkaline phosphatase activity and phosphors limitation in marine macroalgae from the Florida Keys and the Bahamas. MSc thesis, NOVA Southeastern University, Ft. Lauderdale, FL

Weich RG, Graneli E (1989) Extracellular alkaline phosphatase activity in Ulva lactuca L. J Exp Mar Biol Ecol 129: $33-44$

Wynne D (1981) The role of phosphatases in the metabolism of Peridinium cinctum, from Lake Kinneret. Hydrobiologia 83:93-99

Yentsch CM, Yentsch CS, Perras JP (1972) Alkaline phosphatase activity in the tropical marine blue-green alga, Ocillatoria erythraea ('Trichodesmium'). Limnol Oceanogr 17:772-774

Yonge CM, Nicholls AG (1931) Studies on the physiology of corals. V. The effect of starvation in light and in darkness on the relationship between corals and zooxanthellae. Sci Rep (Br Mus Nat Hist) Great Barrier Reef Exped 1:177-211

Submitted: March 6, 2000; Accepted: July 19, 2002

Proofs received from author(s): November 28, 2002 